\title{
TORTURE AND DEPRIVATION OF FREEDOM: THE SPANISH CASE
}

\section{Gemma Ubasart-Gonzàlez}

*** Cite this article: Ubasart-Gonzàlez, G. Torture and deprivation of freedom: the Spanish case. Crime Law Soc Change 60, 401-427 (2013). https://doi.org/10.1007/s10611-013-9455-9

*** ACCEPTED MANUSCRIPT VERSION. The final publication is available at https://link.springer.com/article/10.1007/s10611-013-9455-9

\begin{abstract}
In 2004 Theo van Boven, as Special Rapporteur of the United Nations, alerted the world community that torture and ill-treatment were more than sporadic practices within Spain. Numerous studies carried out by human rights organizations and international institutions endorse this affirmation. This paper attempts to analyse the elements that facilitate cases of torture and ill-treatment while proposing ideas about how to orient political action to eradicate these practices. Situated in the discipline of public policy this paper will try to understand the deprivation of freedom focusing the analysis on the most extreme practices of the State violation of human rights that are produced in these areas. This article first addresses a quantitative description of the presence of torture in Spain. The second section details the historical and political specificities of the Spanish case that are useful in order to understand the question and at the same time in order to establish points of reference for the design of public policy. In the third section the elements that make possible the existence of cases of torture in Spain are analysed, elaborating a typology of static and dynamic elements. The fourth section explains the relationship between democratic culture and torture.
\end{abstract}

Key words: Torture, Human Rights, Prison, Police, Antiterrorism, Spain.

Summary: 1. Torture and ill-treatment in Spain: An Obstinate Reality. 2. The Spanish Specifics: Between the Development of a Culture of Emergency and the Late Democratic Recuperation. 3. A look at structure and action in order to understand Torture in a Democratic State. 4. Citizenship and Democratic Culture. 5. Conclusions: Program of action for the eradication of torture and illtreatment. 
In the report presented in 2004 the special rapporteur from the United Nations, Theo van Boven, already alerted that torture and ill-treatment were more than sporadic practices in Spain. This kind of assertion of a democratic state should have ignited alarm signs. However, reality tends to be disappointing: the Spanish government disqualified Van Boven's report denying its evidences. Unfortunately, little has been change after nine years. Current reports and recommendations published by human rights associations and Official international bodies about the Spanish case continue to report forms of state violence, as the ones previously noted. The majority of which remain unpunished. In fact, in the 2012 annual report (published in 2013) [1] -elaborated by the Coordinator for the Prevention of Torture (CPT) ${ }^{1}$-, 288 cases of torture and ill-treatment (the total number of accessible cases) happened in Spain were analysed concluding that 851 people were affected. This evidence is just the top of the iceberg and the whole report is simply a small register which can be used to identify some tendencies.

As Ferrajoli [2] reminds us, in all states -democratic or authoritarian-it is possible to find traces (with different features and intensities) of the same problem. This statement cannot lead us to conformism but must encourage continuous struggle to eradicate this kind of state violence. Any type of relativism -political, cultural, or economic- can modify the absolute and universal prohibition of those kind of violent practices (Sottas [3]). In this sense, we cannot let the symbolic date of 11th September 2001 escape us, as regards the backwards steps taken in the field of democratic guarantees and human rights. It must be viewed as a moment that breaks the taboo - to publicity of approaches justifying torture, ill-treatment or other violations of human rights -, approaches which one must remember already existed.

Although the presence of torture and ill-treatment is not exclusive to Spain, the numerous registered cases and cruelty here obliges us to deeply reflect about the state of the matter in this context. This confirms the necessity to elaborate public policies that can help overcome the situation. To do so, it is necessary to ask why within a European democratic context, and in a State with recognized international labour in the field of the promotion of human rights (as is Spain), this type of State violence continues to be present and has not ceased since dictatorial times. In this sense, as a hypothesis of the present article the necessity to take into account some specifics of Spain can help us to understand the context and therefore is able to provide a response to the importance of this phenomena in the $21^{\text {st }}$ century: among these we emphasize a) since the 80 s the development of a culture of emergency supported by a punitive anti-terrorist populism; b) as well as the late democratic recuperation through an elite reform process which is related to the difficulty of the consolidation of determined penal and procedural guarantees.

In order to define torture and ill-treatment we adopted the definition of the United Nations Convention against Torture and Other Cruel, Inhuman or Degrading Treatment or Punishment ${ }^{2}$ commonly accepted by academia and the international community. This notes what is understood by torture as "any act by which severe pain or suffering, whether physical or mental, is intentionally inflicted on a person for such purposes as obtaining from him or a third person information or a confession, punishing him for an act he or a third person has committed or is suspected of having committed, or intimidating or coercing him or a third person, or for any reason based on discrimination of any kind, when such pain or suffering is inflicted by or at the instigation of or with the consent or acquiescence of a public official or other person acting in an official capacity". Two elements are emphasized in this definition. The first is the not only physical character of torture and ill-treatment, giving relevance also to psychological or moral pain inflicted. The second element is the specificity of the typology of actor that carries out this violence: they are public employers or other people exercising public functions.

This article first addresses the description of the presence of torture and ill-treatment in Spain by way of a revision of the registered cases. In order to realize this description figures from human

1 The Coordinator for the Prevention of Torture is formed by more than forty entities in the university, professional and associative field that work for the eradication of torture. See also annual reports: www.prevenciontortura.org.

2 Convention approved by the Plenary of the UN 10th December 1984 and ratified by the Spanish State, entered into on October 1987. See http://www.unhchr.ch/html/menu3/b/h_cat39.htm. 
rights associations and official sources have been used. In this first section the recommendations that have been made in recent years by international organizations to the Spanish State after diverse in situ visits or evaluation process are noted. The second section details the historical and political specificities of the Spanish case that are useful in order to understand the question and at the same time in order to establish points of reference to the design of public policy. In the third section the elements that make possible the existence of cases of torture and ill-treatment in Spain are analysed, elaborating a typology of static and dynamic elements. By way of a conclusion and being the most normative part, some ideas about how one should direct political action in order to eradicate these types of practices, as from the perspective of government and public institutions as well as social and cultural organizations.

In order to carry out a plural approach theoretical and methodological tools that come from distinct disciplines are utilized to tackle an object of study of great complexity. In order to do this, the article will review the contributions that are made from legal science, sociology of law and the analysis of public policy ${ }^{3}$ developed from emancipatory perspectives in the context of what is called European critical criminology 4 .

\section{Torture and ill-treatment in Spain: An Obstinate Reality}

The phenomenon of torture is subject to contradictory versions. The official position of Spanish authorities tends to deny its existence. Nevertheless, several local and international organizations have concluded that torture continuous to be practiced in the country. Also, to carry out a description of the state of cases of torture and ill-treatment produced in a specific context is not an easy task. There are numerous difficulties in order to obtain data and those that are registered are normally a lot lower than the real numbers involved. Thus, before entering the specific data there are three considerations.

1) It is worth noting that what is known about torture and ill-treatment comes from social organizations and public authorities which only have a portion of the information about the torture cases that actually occur. Some victims do not report the case and others do not want this made public. This is often due to the will of the tortured person, with the objective of avoiding the risk of making the case public or for the psychological necessity of forgetting the lived tragedy.

2) Of the cases reported publicly, not all are realized as a judicial complaint. The victim and/or lawyer (who deals with the majority of reports of this type) opt to not present the case to the magistrates. Moreover, there are some cases of prosecutions for denouncing torture, a fact that adds more reasons to not report the case.

3) The fact that there is no judicial sentence in reported cases does not mean that indeed there has not been torture or ill-treatment. This institutional violence will hardly be recognized by a magistrate in a democratic country. It will also be extremely difficult for the victim to obtain evidence to prove torture, especially when they occur in places of deprivation of liberty. It deals within uncomfortable reality that the majority of governments try to hide or minimize.

Despite these difficulties, we can establish an estimate of the cases of torture and ill-treatment registered in Spain in recent years, taking into account that the ways through which we know those reported are incomplete. Two sources are utilized: official figures - extracted from the annual report of the "Fiscalía General del Estado" (General Office of the Public Prosecutor of the State) - and the figures supported by the collectives of the report, many of which belong to the CPT. Official figures show the number of previous diligences for torture, degrading treatment and omission of the duty to impede torture. In the last years, there have been changes in the collected data system by the General Office of the Public Prosecutor of the State. Now it is not possible to make a comparison because data of this type of diligences is aggregated with other type of diligences. The second source shows the

\footnotetext{
${ }^{3}$ About public policy see Subirats/ Knoepfel/ Larrue/ Varone [4].

${ }^{4}$ About the tradition of European Critical Criminology see Van Swaningen [5] and Cid/ Larrauri [6].
} 
number of reports that have been received by human-rights organizations that have made it in court or not, and from which one has sufficient information and stories that are credible. The figures of CPT make reference to the number of cases of torture, the figure of people affected by this type of violence and those which have been reported (legally or socially).

It is clear that both sources have their limitations. The first sample reported cases in court and found in previous investigations. This presents two problems: they do not record unreported court cases and on the other hand, this data could hide false allegations. The second source is also problematic because it only records cases known to social organizations. In any case, this data helps us get a rough idea of the reality of torture in Spain. The data must be accompanied by qualitative information to understand the magnitude of this institutional violence.

With the figures obtained by these CPT sources it is possible to conclude that during the first years of the $21^{\text {st }}$ Century there is constancy of at least 8000 reports, which gives an estimated average of more or less 700 reported cases annually. CPT figures include Torturaren Aurkako Taldea (TAT) ${ }^{5}$ figures.

Table 1. Torture in Spain (estimate of the people affected)

\begin{tabular}{|l|l|l|l|l|l|l|l|l|l|l|l|l|l|}
\hline & 2001 & 2002 & 2003 & 2004 & 2005 & 2006 & 2007 & 2008 & 2009 & 2010 & 2011 & 2012 & Total \\
\hline $\begin{array}{l}\text { Fiscalía General del Estado } \\
\text { (General Office of the } \\
\text { Prosecutor of the State) }\end{array}$ & 651 & 853 & $\ldots$ & 753 & 591 & $\ldots$ & $\ldots$ & $\ldots$ & $\ldots$ & $\ldots$ & $\ldots$ & $\ldots$ & $\ldots$ \\
\hline CPT (includes TAT) & 758 & 747 & 580 & 755 & 596 & 610 & 576 & 689 & 624 & 540 & 853 & 851 & 8179 \\
\hline
\end{tabular}

Source: Del Cura [7, 8]; figure completed with CPT sources.

The reports of TAT present a longer temporal view. It deals with figures geographically localized in the Basque context, however they are the only ones that it is possible to access. There is no association in Spain that make a systematic collection. One must also point out that many of the cases collected by this organization refer to torture produced under the application of the incommunicado ${ }^{6}$ detention. In this manner, the presence/absence of these cases fluctuates according to the political situation in the Basque Country and Spain. For example, during the last two peace processes (1998-99 and 2006-7) the incommunicado was reduced and therefore also diminished in a parallel form the cases of torture and ill-treatment in relation to the typology of politician arrested.

Figure 1. Tortures registered in the Basque Country (1992-2007)

\footnotetext{
${ }^{5}$ About TAT (sigla of Group Against Torture) reports see www.stoptortura.org.

${ }^{6}$ The figure of incommunicado is the legal recognition of the possibility of submitting an arrested subject accused of terrorism to solitary confinement for five days without the possibility of having access to a doctor or solicitor of their trust, and without the possibility of communicating their situation to relatives or friends.
} 


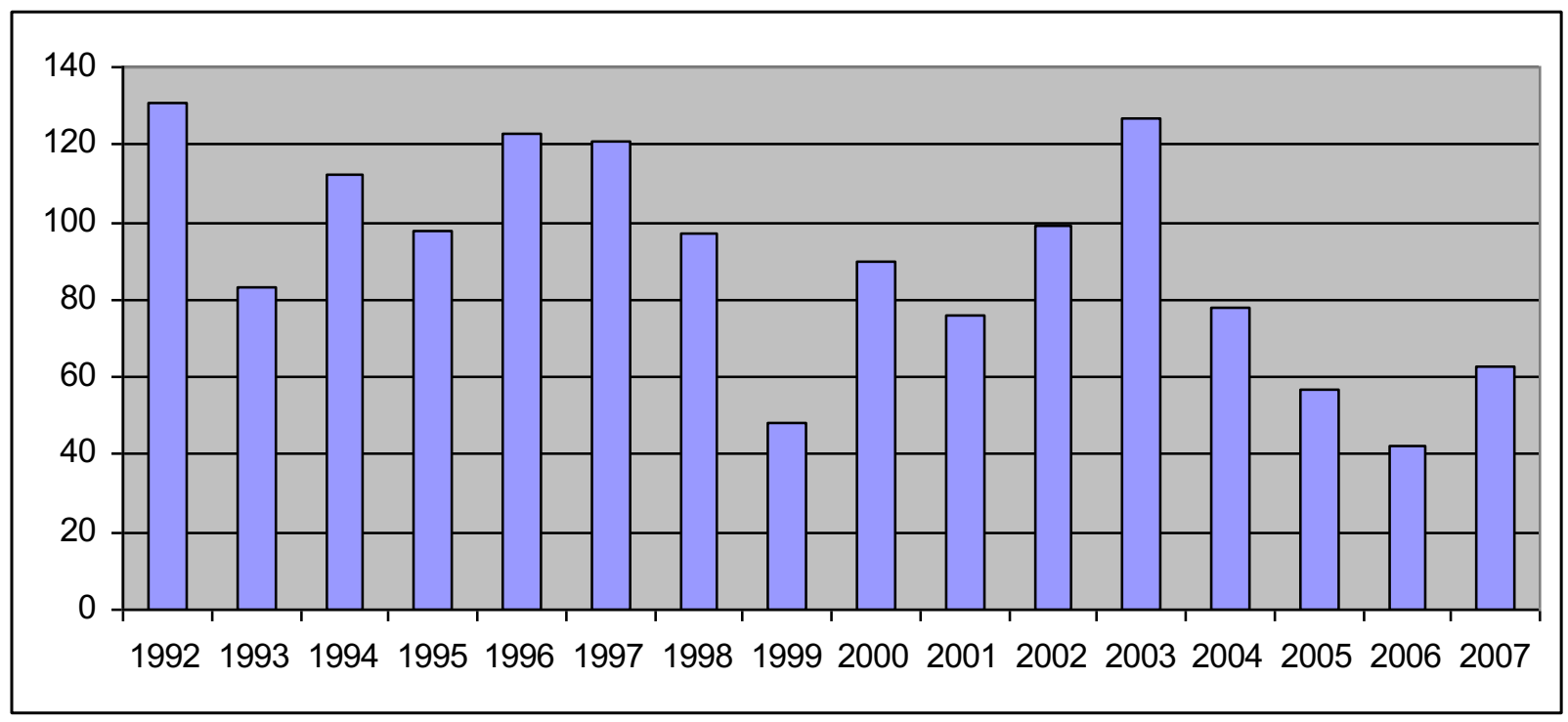

Source: TAT database ${ }^{7}$.

As is noted, many of these cases of torture and ill-treatment have been produced during the application of incommunicado detention. TAT estimates that the number of people arrested under this figure in relation to the Basque conflict since the approval of the Spanish Constitution (1978) until 1988 has been approximately 6.400 people; and during the period between 1989 and 2006 counts as 2.700 people. In total one speaks of a number of approximately 10,000 people arrested and put in incommunicado detention. Of these, TAT affirms that more than $95 \%$ have been the object of irregular treatment and more than $90 \%$ object of aggressive treatment of different forms and intensities. Despite this, it is affirmed that the practice of torture was not produced in the same forms and levels of intensity throughout this period: in the first period (1978-88) practically all those people arrested and put in "incommunicado" detention were subject to torture or ill-treatment reducing this rate in the following period.

If we take into account the reported cases interposed of torture in the last 30 years of democracy these figures reach 5.500 in the Basque context only, elevating the TAT figures to 7,000 people estimated. In the same sense that we noted previously, the number of reported cases interposed is less than the number of occurred torture (and also less than those known by human rights organizations). Despite this one must note that the percentage of reported cases in relation to occurred cases of torture or ill-treatment rises in contexts where civil society exists endowed with organizations that offer technical help and human support to the victims.

\section{The Reports and Recommendations of International Organisations}

For numerous years, the Spanish situation in relation to torture and ill-treatment is a cause for concern in international organizations and associations of the defence of human rights ${ }^{8}$. Many times they have proposed a series of measures that could, if not eradicate, but prevent the practice of torture in Spain. We can emphasise the following as important, ordered by actuality (reports of the first years of the $21^{\text {st }}$ Century):

- The report about Spain by the Committee for the Prevention of Torture of the Council of Europe, after the visit effected in 2011, published in April, $2013^{9}$.

\footnotetext{
7 Difficulties in accessing the TAT database, precluded the actualization of data.

${ }^{8}$ See "Recommendations of international organizations" in Annex.

${ }^{9}$ Between the 2001 report and the 2011 report, there are several other reports are available on CPT website [9].
} 
This is the last published report of Official international bodies about Spain. In this report, Committee for the Prevention of Torture analyze fulfillment of rights and guarantees in different areas of deprivation of liberty, as well as in the management of public order. Regarding incommunicado detention, it recommends: "the Spanish authorities to carry out a thorough and independent investigation into the methods used by members of the Guardia Civil", "whenever persons allege illtreatment by law enforcement officials, the prosecutor/judge should record the allegations in writing, order immediately a forensic medical examination (...) and take the necessary steps to ensure that the allegations are properly investigated" and "steps to be taken to ensure that three specific safeguards are applied vis-à-vis all persons held in incommunicado detention, namely: the notification to the family regarding the fact of detention and the detained person's whereabouts; the possibility of being visited by a personal doctor together with the forensic doctor appointed by the investigative judge; 24hour video surveillance and recording of the detention areas".

When the report discusses the issue of ordinary custody points "the Spanish authorities to remain vigilant in their efforts to combat ill-treatment by law enforcement officials. In particular, these officials should be reminded that no more force than is strictly necessary should be used when effecting an apprehension and that, once apprehended persons have been brought under control, there can never be any justification for striking them". Referring to the jail, the report says "the Spanish authorities to continue to pursue policies designed to put an end to overcrowding in prisons"

- The conclusions and recommendations of the Human Rights Committee of the United Nations to Spain, after the 54 period of sessions from the $13^{\text {th }}$ to the $31^{\text {st }}$ of October, 2008.

This report alerts the Spanish government of the lack of fulfillment of the International Covenant on Civil and Political Rights and urges it to take concrete measures. With regards to the occurrence of torture and ill-treatment, the Committee detects many problematic areas, among them: the failure to apply a global strategy against this evil and failure to adopt a national mechanism to prevent it; continuing incommunicado detention, and the impossibility for this group of detainees to be assisted by their reliable doctor or lawyer; the failure to record all interrogations in police stations and detention centres; as well as the excessive duration of provisional imprisonment.

Thus, the Committee affirms that "The State part should accelerate the adoption process of a national mechanism to prevent torture, in accordance with that which is decreed in the Optional Protocol to the Convention Against Torture and Other Cruel, Inhumane, or Degrading Treatment or Punishment, keeping in mind the recommendations of the different international bodies and experts and the opinion of the civil society and of all non-governmental organizations that participate in the fight against torture" With regards to incommunicado detention, "The Committee once again recommends adopting the necessary measures, including legislative, to ban the regime of incommunicado detention once and for all, and that all detainees are acknowledged of their right to select a lawyer who they may consult in total confidentiality and who may be present during questioning. Likewise, the State party should make systematic use of audiovisual means to record cross-examinations in all police stations and detention centers".

- The report of the Commissioner for Human Rights of the Council of Europe after his visit to Spain, published in March, 2005.

The recommendations in this report that stand out with regards to torture and ill-treatment refers to the need to "investigate rapidly and thoroughly all allegations of torture or ill-treatment, and deaths of detainees in police stations, premises of the Guardia Civil and other police authorities, applying where necessary the appropriate disciplinary and criminal sanctions"; "create the necessary mechanisms for compensating victims of torture and ill-treatment, where necessary through legislative reforms"; and "review the current regime of incommunicado detention so as to allow the detainee to meet his or her counsel in private, at least once".

- The recommendations from the visit to Spain in October of 2003 of the Special Rapporteur for 
the Question of Torture of the United Nations, published on the 6 ${ }^{\text {th }}$ of February, 200410.

The recommendations of Theo van Boven are extensive and clear. Among other things, he indicates that "Taking into account the recommendations of international monitoring mechanisms, the Government should draw up a comprehensive plan to prevent and suppress torture and other forms of cruel, inhuman or degrading treatment or punishment". The Special Rapporteur emphasizes incommunicado detention in his report: "Since incommunicado detention creates conditions that facilitate the perpetration of torture and can in itself constitute a form of cruel, inhuman or degrading treatment or even torture, the incommunicado regime should be abrogated". With regards to this matter he also notes that "All persons held in detention by law enforcement agencies should promptly and effectively be ensured (a) the right of access to a lawyer, including the right to consult the lawyer in private; (b) the right to be examined by a doctor of their own choice, it being understood that such examination may take place in the presence of a State-appointed forensic doctor; and (c) the right to have relatives informed of their arrest and place of detention. He also recommends that: "Each interrogation should begin with the identification of all persons present. Complaints and reports of torture or ill-treatment should be investigated promptly and effectively". Reparation of the victims is also considered as a recommendation: "Legal provisions should be effectively and expeditiously implemented to ensure that victims of torture or ill-treatment obtain redress and adequate reparation, including rehabilitation, compensation, satisfaction and guarantees of non-repetition".

- The conclusions and recommendations of the Committee Against Torture of the United Nations to Spain, after the 29 period of sessions from the $11^{\text {th }}$ to the $22^{\text {nd }}$ of November, $2002^{11 .}$

CAT as well as other organizations views "incommunicado" detention as dangerous. Therefore: "The Committee invites the State party to consider precautionary measures to be used in cases of incommunicado detention, such as: (a) A general practice of video recording of police interrogations with a view to protecting both the detainee and the officials, who could be wrongly accused of torture or ill-treatment. The recordings must be made available to the judge under whose jurisdiction the detainee is placed. Failure to do this would prevent any other statement attributed to the detainee from being considered as evidence; (b) A joint examination by a forensic physician and a physician chosen by the detainee held incommunicado. CAT also shows concern for the lack of investigation and punishment for the misdeed of torture. Therefore "The Committee reminds the State party of its obligation to carry out prompt and impartial investigations and to bring the alleged perpetrators of human rights violations, and of torture in particular, to justice"; and "The Committee recommends that the State party should ensure the initiation of disciplinary proceedings in cases of torture or illtreatment, rather than await the outcome of criminal proceedings."

- The report about Spain by the Committee for the Prevention of Torture of the Council of Europe, after the visit effected in July 2001, published in March, 2003.

After verifying the evidence of the existence of torture and ill-treatment in the Spanish State, amongst other measures, "The Committee calls upon the Spanish authorities to take concrete action to implement- without further delay - the following longstanding CPT recommendations: - all persons deprived of their liberty to be granted, as from the very outset of their detention, a fully-fledged right of access to a lawyer (...), it being understood that, in the case of persons held incommunicado, the lawyer may be appointed on their behalf; - the period of time for which persons detained by the law enforcement agencies may be denied the right to have the fact of their detention and the place in which they are being held made known to a relative or other person of their choice to be shortened to a maximum of 48 hours; - persons held incommunicado to be guaranteed the right to be examined by a doctor of their own choice, it being understood that such a second examination may take place in the presence of a state-appointed forensic doctor".

\footnotetext{
10 There are also interesting the conclusions of the Special Rapporteur on the promotion and protection of human rights and fundamental freedoms while countering terrorism, Martin Scheinin, Mission to Spain.

11 In the $5^{\text {th }}$ periodical report, CAT did similar recommendations for the Spanish Government. See CAT/C/ESP/CO/5
} 


\section{The Spanish Specifics: Between the Development of a Culture of Emergency and the Late Democratic Recuperation.}

The importance of the phenomena of torture and ill-treatment in a democratic country like Spain obliges us to deepen the case and proceed to the identification of specificities that help us explain the why of this situation, as well as facilitate a future design and implementation of public policies in order to confront this type of State violence. Two elements will be emphasized in this article about the specifics of the Spanish case: the development of a culture of emergency as a response to the Basque Country national conflict and the late democratic recuperation that did not occur until the late seventies via an elite pact of reforms. The importance of cases of torture related to the Basque conflict does not lie in its quantity but the systematic nature in which these occur (it should take into account the existence of exceptional legislation with significant gaps of guarantor). Also relevant is the phenomenon of "contamination": if one justifies torture for terrorists (or suspected terrorists) it is easy for this permissiveness to be transferred to other groups.

\subsection{Development of a Culture of Emergency}

The first element to highlight affirms those parts of the cases of torture and ill-treatment that are produced in Spain that have to be understood as directly or indirectly linked to the broader framework of the application of an exceptional anti-terrorist legislation ${ }^{12}$, with all the discursive and ideological constructions, as well as material, that is accompanied by it. It not only deals with legislation but also a culture of emergency ${ }^{13}$ that permeates the distinct institutions of the penal system (police, courts and prison) as well as in the political culture of citizens, justifying specific State violence (Bergalli [15]). An example of the materialization of exceptional anti-terrorism is the existence of the "incommunicado". This facilitates a space of defencelessness and impunity.

The bad resolution of the territorial question in the democratic transition in the second half of the 1970s, and the recourse to repressive mechanisms before dialogue during the entire democratic period, amongst other reasons, consolidated the presence of the armed organization Euskadi Ta Askatasuna (ETA) ${ }^{14}$. This was and is the principal justification of the construction of the antiterrorist legal and political framework of the Spanish State. Since the birth of the democratic State a double penal route exists: the "ordinary" and the "exceptional". This exceptional regime is utilized also to combat other phenomenon, including the yihadista violence entering into the $21^{\text {st }}$ century.

Although in many countries the events of September 11th decisively influenced the direction of penal and prison policies, in Spain it only meant a continuation of existing practices. Illiberal measures in Spain were developed in the eighties as a result of internal dynamics and these have not changed substantively since the attacks in New York and Madrid. This means, that at the international level it gave free rein to what was already being carried out; also exporting to the EU certain repressive policies. ${ }^{15}$.

\section{The construction in Europe}

It is not the only case in Europe that developed a Culture of Emergency (see also Italy, RFA or Great Britain). But it is the only case that has hardened in terms of the State response constructed from the seventies and eighties to combat what at that time was characterized as "revolutionary terrorism" (Crenshaw [21])16. In the framework of different liberal democracies, and with the pretext of confronting a supposed terrorist threat, a series of illiberal measures were elaborated (Bigo et al. [23]).

\footnotetext{
12 About antiterrorist exceptional legislation in the Spanish State see Arzuaga [10, 11], Guittet [12] and López-Garrido [13].

13 About culture of emergency see Baratta/Silbernagl [14], Bergalli [15], Ferrajoli [16] and Ubasart [17].

${ }^{14}$ About history of ETA see Bruni [18], Casanova [19] and Ibarra [20].

15 About this argument see Guittet [12].

16 About political violence see Ruggiero [22].
} 
These ended up forming an authentic culture of fear and exception, of the arbitrariness and vulnerability of the Rule of Law. This was preceded by an elaboration of specific anti-terrorist legislation, to the political utilization of tribunals, to the penitentiary policy of isolation, and to the resources of State terrorism - be it in the form of attacks, disappearances or torture.

Currently the development of the Culture of Emergency in Spain has achieved high levels of illiberalism, a deepening in forms exercised up to three decades ago in other contexts. Therefore, we are currently confronting illegalisation of political parties, the closing of mass media, the charges of crimes of terrorism to members of Basque social or cultural organizations and businesses, etc. Maintaining, as already noted, a culture and legislation that facilitates the existence of torture and impunity when faced with it. Primarily, as the practice of legitimate torture against those supposed terrorists, in order to subsequently be seen as normal in other freedom private subjects and spaces of imprisonment.

To understand the current antiterrorist framework of Spain we have to go back to the seventies, when Italy and Germany began to develop the so-called "culture of emergency". One often emphasises that in these states the revolts of 1968 that shook the entire planet were not exhausted this year. The end of the 1960s was only a starting point in the extension and radicalisation of social protest. In these circumstances important armed groups in the most radical sectors were consolidated. In Italy these were the years of the "autonomia operaia" and the Red Brigade, but also of Black terrorism and the strategy of tension. The conflict in Germany was also important although it was not as socially extended as the mobilisation in Italy. Faced with this conflict, the State did not wait to react and it did not simply activate the mechanisms of repression established by constitutions and laws that govern democratic states. These faced substantial modifications, operative and symbolic of policies related to the penal system.

The use of exceptionalism in this era was justified at a theoretical and political level for its temporal character, circumstantial nature and for its proximate expiration date. It seems, however, in light of the empirical evidence that the situation was different. These legislations, judicial and police practices, and this culture did not disappear: it was consolidated as a model that other states implemented. This is the case of Great Britain or Spain to only name two examples. In order to confront a conflict of national base (although not the only) a range of similar measures were resorted to.

\subsection{Late Democratic Recuperation}

A second element to take into account is the relatively recent dictatorial past and late democratic recuperation. In 1975 Franco died and in 1978 the Spanish Constitution was approved, the product of a reformist pact between elites but forced by the strong tensions and social conflicts of the era. This fundamental law has to be understood in the broader framework of the so-called "social constitutionalism" that was developed in Western Europe from the end of the Second World War, materializing in the Spanish case thirty years later. This was characterized for being the articulation of the formula of the social and democratic rule of law, the consecration of a wide range of fundamental rights and procedural guarantees, together with mechanisms for the protection of both, the constitutional emergence of the goal of resocialization of the exclusive punishment of liberty, together with other elements of guarantee (Rivera [24]). One could therefore say that, in the Spanish State a liberal democratic regime was not consolidated until after the death of the dictator. It was an undemocratic anomaly in Western Europe (together with Portugal and Greece), although it did not produce an external intervention relevant to change the direction of history. One of the reasons could be that these three dictatorships did not doubt the distribution of the areas of influence determined by the pact in Yalta (1945).

The authoritarian political regime profoundly transformed, among others, the inherited police apparatus: all forces of security and the struggle against political dissidence becoming militarized and located at the centre of police activity. This tendency becomes more acute at the end of the dictatorship for the important social and political conflicts that are registered (Jaime-Jiménez [25]). The members of the security forces, like the political and corporative culture of the military apparatus survived the 
death of Franco, and the military and police sphere is one of the spaces with the least changes of regime. Some similar dynamics are also identified in the other institutions of the penal system like the courts and prison.

Therefore one could say that in the Spanish case the democratic rule of law was arrived at late by means of an elite pact in a context in which not only determined aspects of the Welfare State began to be questioned, but also the principles of penal guarantees. These elements have repercussions on the process of the formation of the structure of the mechanisms of protection of a population deprived of freedom. Structural and dynamic mechanisms are related to the rules of the game and the corporate professional culture (of the institutions of the penal system) as well as those of citizenship. Following a schematic mode and as is subsequently analyzed, this situation materializes in: a) The adoption of legislation, or rules of the game, with gaps identified in relation to guarantees in order to respect human rights. b) The existence of a corporative culture in the diverse institutions of the penal system (police, courts and prison) more anchored to a dictatorial past than a democratic present, above all during the eighties. c) The configuration of a citizen's political culture not very demanding with respect to guarantees and human rights, above all in relation to the deprival of personal freedom (and more extreme with accusations of terrorism).

\section{$\underline{\text { 3. A look at structure and action in order to understand torture in a Democratic State }}$}

The existence of torture and ill-treatment responds to a conjunction of static and dynamic elements of the diverse institutions that configure the penal system. To carry out a complex analysis of the elements that intervene in the development of the phenomena can help us to understand the context in which it is situated - as well as to design adequate measures in order to prevent this practice. Therefore, in this section, to study the nature of these elements utilizing legal science, the sociology of law and public policy discipline are used as theoretical and methodological perspectives. We confirm that the study of the framework in which cases of torture and ill-treatment cannot be carried out only from a legislative analysis, as many of the dynamics are not exclusively aspects of formal legality.

The definition of the concept of a penal system varies according to the predominant discipline from which it is operating, as well as depending on the analytical level in which the researcher is situated. In terms of features one can affirm that two distinct conceptions exist: the static penal system - that is studied from legal sciences - and the dynamic penal system - that is studied from the sociology of law (in order to elaborate a diagnostic) and from the analysis of public policy (in order to propose some measures for public administration). According to Bergalli [26] we describe the concepts of static and dynamic penal systems.

Static penal system. The objects of study of legal science in the penal sphere are the normative contributions that are made from penal procedural law. In the broader conceptions of this concept the police law and the penal implementation law are contemplated. It deals with a static and abstract vision in which one only perceives the features of generality, universality and abstraction that characterize the law. An analysis of this type, based on the observation of the regulations/rules of the penal system, permits one to analyze the legislative framework, the theoretical rules of the game in which we move. However, it does not help us to understand the complexity of the penal system, understood as a collection of apparatus that act and make real the regulations designed in an ideal plan.

Dynamic penal system. The objects of study of sociology of law are the behaviours provoked by the regulations and their practical application. In countries where the rule of law operates, the punitive control is implemented by means of specific institutions to which are attributed the capacity: the police, penal jurisdiction and the prison (or other institutions of deprivation of the freedom). These three institutions, anticipated by the constitutional order in order to apply or exercise punitive control, form what has been called the dynamic penal system. This concept of the penal system is also taken into consideration by the analysis of public policy that offers the possibility to carry out proposals and measures to implement. 
The differentiation between Static and Dynamic penal systems is more theoretical than an accurate reflection of reality. It is clear that the legal framework conditions the practices undertaken by various elements of the criminal justice system, and that therefore everything is interconnected. Despite this, and in order to better understand social reality and the phenomenon we are studying, we hold that it is interesting to analyze, on the one hand, those elements found in the legislation that can facilitate the existence of torture, and on the other hand, take account of the corporate practices that occur within the police apparatus, the judiciary and custodial institutions (jails, juvenile centers, centers for immigrants...).

\subsection{Static Elements and Torture (The Structure)}

Therefore, from a structural perspective it is necessary to consider as factors which enable the practice of torture and ill-treatment those elements that are related to the configuration of the formal rules of the game, or in other words, with penal and procedural legislation. The identification of the gaps of guaranteeing of fundamental rights in the current legislation is a first step, although not the only, in order to identify elements that could facilitate the presence of torture in a specific context. Regulatory elements that may allow the existence of torture are the easiest to indentify when we make a state of the art. In this regard, it deals with elements that are more easily detected by international agencies and human rights organizations, simply from a study of the regulatory framework. In the Spanish case one can identify three elements.

3.1.1. The existence of the figure of incommunicado that makes possible the detention of people accused of terrorism for a period of five days without permission for doctor or lawyer of trust, nor the communication of the detention.

The Spanish legislation presents a series of dispositions that guarantee the basic rights of the detained. Amongst others, the article 17.3 of the Spanish Constitution (CE) and the article 520.2 of the "Ley de Enjuiciamento Criminal" (LEC, procedural legislation) guarantees the right of the detained to be informed, without delay, to the causes of the detention and of the accusations against him/her, to keep quiet and not declare, to make someone of their choice aware of the fact of their detention and the place where they are being held, as well as the appointment of a solicitor in all diligences, in terms of police and judicial. Facing these guarantees, articles 520 bis and 527 of the same LEC restrict considerably these rights for "people integrated or related to armed groups or individual terrorists or rebels". It prepares the possibility of amplifying the period of detention under police custody from 3 to 5 days, denying the attendance of a lawyer or doctor of trust of the detained or the possibility of communicating their detention to friends or family members. To this one must add the reform introduced by the LO 13/2003 that would make possible in some cases the extension of incommunicado to eight days further.

Incommunicado detention applied under the Antiterrorist Legislation is a physical and judicial space of impunity for torture and ill-treatments. Incommunicado detention also can be, by itself, a Cruel, Inhuman or Degrading Treatment or Punishment as it was pointed out by the Special Rapporteur on the question of Torture, Theo van Boven in his Report on Spain (2004). Antiterrorist Legislation has been historically applied to Basque origin people. Since September 11th, 2001 and, in Spain, specially since March 11 th , 2004, Antiterrorist Legislation has been also applied to Islamic people, some of whom have denounced tortures. In recent years, different empirical studies have approached the way in which incommunicado detention is applied, paying special attention to its motivation, lenght, judicial control, the number and moment of statements made at the police station and the result of their actions, also to eventual reports of ill-treatment and their investigation ${ }^{17}$. Some conclusions put

17 1) Orbegozo / Perez / Pego [27] investigation granted by the Ararteko -Office of the Ombudsman for the Basque Country. This report focuses its attention on the legal proceedings in which incommunicado detention was applied in 2001. It monitors the cases along the years following until the moment a sentence; 2) Dirección de Derechos Humanos del Gobierno Vasco [28] - Basque Government Directorate of Human Rights. This report makes a statistical/scientific analysis of cases in which the incommunicado regime was applied between the years of 2000 and 2008. It analyses the allegations of ill-treatment/abuse presented using independent variables of a demographic, procedural and criminological nature, which look both at their 
in relation incommunicado and torture. For exemple, on the 2000-2008 period, the Basque Government Directorate of Human Rights [27] identify 957 incommunicado detention. Of these people, 634 say that have been tortured and 446 denounce torture in court.

\subsubsection{The Maintenance of determined types of penitentiary isolation.}

There exist two types of penitentiary isolation identified in the Spanish legislation. Firstly, as disciplinary sanction: this can be applied for by the direction of prison of up to 14 days without the necessity of previous authorization of a "Juez de Vigilancia Penitenciaria" (Parole Court), and can be prolonged with their consent. A second type of isolation is the called "art. 10" of the Penitentiary Law or also known as the first grade of classification. This is applied to prisoners classified as being of maximum danger and failure to adapt to the ordinary regime (Cabrera/ Rios [30]). In Spain (not in Catalonia, the only territory with the penitentiary jurisdiction transferred) the FIES regime exists related with this article. In this way, whatever type of isolation could be considered by itselfilltreatment, but at the same time it affirms as a space the possibility of the existence of abuse to isolated person.

3.1.3. The recognition of the figure of the "indulto" (pardon), utilized in order to pardon torturers in the small number of cases in which the courts have dictated a conviction.

An "indulto" (pardon) is the suppression by the executive power of a sentence passed by the judiciary. It is a measure of grace granted by the government to people convicted in a trial. This instrument has meaning in an authoritarian country but not in a democratic State. The separation of powers can not permit denying a judicial decision by the executive power. One of the cases that has arrived to public opinion is the prisoner release of the ex General of the Civil Guard, Rodríguez Galindo who despite fulfilling a sentence of 72 years of prison for kidnapping, torture and assassin of Lasa and Zabala (in Basque Country during the period of GAL). He was released on the 29th July, 2004. The "Dirección General de Instituciones Penitenciarias" (General Directorate of Penitentiary Institutions) under the PSOE government permitted the ex general after completing four years and four months in prison, continued his sentence under home arrest. Another recent example is the case of 4 local policemen from Vigo (Galicia), condemned for illegal detention and sticking of the Senegal citizen in 1997. They were condemned to 3 years of prison and 8 years of incapacitation. None of the officials went to prison; they were temporally separated from their jobs, but came back to them after 2005 Pardons (confirmed in 2007).

\subsection{Dynamic elements and torture (The Action)}

The sociology of law has shown us that not all of the dynamics of the penal system can be understood through a legislative analysis; it becomes necessary to probe further in order to understand the complexity of the social phenomena, object of reflection in this present article. From a dynamic perspective, one should observe certain practices developed by the diverse institutions of the penal system: the police apparatus, the courts and the institutions of deprivation of freedom. It is necessary to identify those behaviours that, despite putting in doubt determined fundamental rights, become normalized and reproduced due to a corporative culture present in these state bodies. That is, it takes into account the gaps of guaranteeing detected in the practices of the various levels of the criminal justice system (and not only in the rules).

It should be noted that although most cases of torture and ill-treatment are inflicted by police or prison officers, the actions or omissions of judges and prosecutors are also relevant to enable more episodes of this type to happen. Modifying the behavior of these state bodies is not as simple as the

content and at their distribution by sex, age, place of detention, reason for detention, legal situation following detention, year of detention and the Central Criminal Court where the case was heard and the police force that made the arrest; 3) De la Cuesta / Muñagorri [29] of the Instituto Vasco de Criminología -Basque Institute of Criminology. This report diagnoses the potential infringement of the fundamental rights of detainees for crimes deriving from application of anti-terrorist standards. It addresses both the dogmatic analysis of existing legislation and the empirical application of incommunicado to 232 detainees from 2000 to 2007. 
legislative changes that can involve the assessment prepared in the previous section. It would require the design and implementation of public policies and programs aimed at changing corporate dynamics entrenched in the various levels of the criminal justice system. If we take into consideration the cases reported (public or legal) registered by the CPT during the year 200718 these are driven in the majority of the cases by members of security forces of all types and administrations (local, regional and stately). Taking these figures with all the necessary precautions previously identified, the report affirms that in 613 cases police were responsible (National Body of Police, Civil Guard, Local Police and Autonomous Police), 83 prison workers and 14 other professionals (personnel from juvenile centers, port police etc...). We therefore observe the importance at a quantitative level of cases of torture and ill-treatment exercised by security forces and bodies. In the majority of cases this violence is exercised against excluded or vulnerable people (migrants, sexual workers, the poor...) or against political militants (be it in application of the anti-terrorist law or not). The motives for why it is exercised are various: destroy the dignity of a person, the search for a guilty plea or the obtaining of information.

Before we enter into the analysis of each institution of the penal system we present a table extracted from the cited report of the CPT in which the collectives that suffer aggressions are related to the bodies of reported public employers.

Table 2. Relation collectives that suffer aggression and public employers' bodies reported in 2007

\begin{tabular}{|c|c|c|c|c|c|c|c|c|c|}
\hline 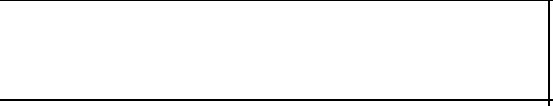 & $\begin{array}{l}\text { Incomu- } \\
\text { nication }\end{array}$ & Migrant & $\begin{array}{l}\text { Social } \\
\text { Mov. }\end{array}$ & Minors & Others & Prison & Traffic & Deaths & TOTAL \\
\hline Cuerpo Nacional de Policía (National Body of Police) & 25 & 24 & 62 & 0 & 44 & 0 & 4 & 10 & 169 \\
\hline Guardia Civil (Civil Guard) & 18 & 19 & 12 & 0 & 10 & 1 & 1 & 4 & 65 \\
\hline Policía Local (Local Police) & 0 & 37 & 32 & 0 & 106 & 0 & 45 & 6 & 226 \\
\hline Policía Autonómica (Autonomous Police) 19 & 0 & 8 & 121 & 0 & 21 & 0 & 1 & 3 & 154 \\
\hline Funcionarios de Prisión (Prison Workers) & 0 & 11 & 0 & 0 & 0 & 81 & 0 & 37 & 129 \\
\hline Others & 0 & 3 & 0 & 12 & 1 & 0 & 0 & 3 & 19 \\
\hline TOTAL & 43 & 102 & 227 & 12 & 182 & 82 & 51 & 63 & 762 \\
\hline
\end{tabular}

Source: CPT [31]

\subsubsection{Torture and the Police Apparatus}

According to sociology of law, police practices ontologically are marked by an important grade of arbitrariness and by a lower level of penal guarantees and processes than that which other institutions of the penal system enjoy. Luigi Ferrajoli, philosopher of law and highest representative of a penal guarantism, affirms that there exist three penal subsystems: the ordinary penal subsystem, the penal subsystem of police, and the penal subsystem of exception. Ferrajoli [16] carries out research using the Italian case and it is applicable to the analysis of the Spanish case.

The first of the sub-systems enjoys higher levels of guarantees, elements that one sees cut in the second, in which situated as a space inclined to arbitrariness and the lack of guarantees. This is more pronounced in the penal subsystem of exception in which we include the types of legislation and practice that have been noted, related to accusations of terrorism. In the same sense, the author observes that "in the passage from the highest levels to the lowest levels of the law - from the constitution to ordinary legislation, from ordinary legislation to its judicial application, a not further still, its police application - one notes a décalage, a real fall of normative guarantees" (Ferrajoli [16]:725).

Whilst the structure of the rule of law carries some inevitable tensions between the different levels of legislation, an element of perversion is introduced when the management of conflicts tends to

\footnotetext{
18 The only year in wich data are disaggregated.

19 Ertzantza (Basc police) and Mossos d'Esquadra (Catalan police).
} 
transfer into lower levels, described here, modifying the nature of the penal system as a whole. In other words one identifies a tendency to transfer the management of conflicts to the police subsystem and that of exception. Ferrajoli reports that: "a hollowing out of almost all penal guarantees and processes are produced and a growing administration of penal law, is expressed in its mutation tendency from a strictly retributive system, driven to prevent future crimes only by means of the punishment of past and proven crimes, to a system of a preventative tendency, driven to confront the simple suspicion of past crimes or simple danger of future crimes" ([16]:725-726).

One of the consequences of transferring powers to the police apparatus is the increased role it takes on in the investigation phase of cases (particularly so in cases of terrorism). Collection of evidence incriminating other people or the detainees themselves frequently takes place during the five days of incommunicado detention in police custody, in other words, through torture. A paradigmatic instance of this can be found in the case that became known as "The Iruñea 4". Charged with membership of an ETA unit that had assassinated a town councillor, they were held in remand for 2 years on the sole basis of self-incriminating statements obtained during incommunicado detention. In 2004, the four young Basques were released from prison when varied documentation arose in France showing the lack of connection between the detainees and the events. It is important to say that $64 \%$ of incommunicado people make one or more statements in police, despite they have the right of not testifying [28]. Additionally the incidence of the police's statement as an inculpatory proof for the convictions is very high: $67.39 \%$ of individuals who have been convicted, they police statement has been taken into account as evidence incriminating.

Also, an important part of the reported cases registered for torture and ill-treatment are related to the management of public order (Fernández [32], Fernández/Ubasart [33]), as well as those that are related to isolation in the anti-terrorist material exposed in the above section. According to studies about public policies one can draw different models of public order policies or "policing protest some further away from others in respect to fundamental rights" (Della Porta [34]. It is fitting to say that in these policies where surely it is better to consider the tensions between power and the law - or the monopoly of state violence according to the words of Max Weber and the limitation of the power of life and death. In modern democratic societies the challenge of control of protest is one of the most delicate questions that the police apparatus must confront. What is at play is not only personal liberties but also the rights of political participation of the citizenry and, the essence of the democratic system (Della Porta/ Reiter [35]:12).

In this way, one can say that there are many ways to confront political conflict in the street, and that the form chosen depends to a greater or lesser degree on fundamental rights (be them civilians or politicians). In the Spanish case there exist great difficulties in order to implement innovations in the police apparatus, still anchored to dynamics influenced by the dictatorial past. Some newly created police bodies, as the autonomous (Mossos d'Esquadra o Ertzaintza), although in a limited way have shown to be more inclined to adopt models based on tolerance and flexibility.

As examples, there have also been police abuse cases especially of concern. We want to point out the Roquetas de Mar case in Almería, where a citizen that went to the Guardia Civil police station to put a complaint, was finally allegedly killed by the agents after a torture session in the street (CPT Report of 2005, 2006 and 2007). Though the existence of such evidences - as security video records - in the trial was settled that this death was not caused by the tortures. These kind of situations have inspired an International Amnesty Report on police brutality in Spain titled La sal en la herida [36].

\subsubsection{Torture and the Courts}

Despite what we have affirmed, the responsibility of the existence of torture does not fall solely on the police apparatus. The courts, as guarantor the fulfilment of fundamental rights of those people deprived of freedom, becomes a participant in the type of violence is produced. Distinct actions facilitate torture and ill-treatment that penal jurisdiction carries out, amongst these are:

- Lack of effective research of reports of torture, slowness of the investigation and lightness of imposed sentence. In certain cases, these crimes have been politically rewarded. 
Human rights associations and international organizations, as did the court of Strasbourg, have repeatedly reported the lack of effective investigation by the Spanish courts; by noting the quickness of archiving of reports against public workers and their limited and deficient investigation. However, if a compliant reaches the first obstacle, various years can pass by until a sentence can be obtained which finalizes the process: the average can be four to five years, for those complaints of injury, this period can importantly be amplified if the accusation is for the crime of torture. In some of these cases the holding of judgement has been delayed for up to 20 years. In this sense, the UN's Special Rapporteur in order to question torture in their report published in 2004, "call's attention to the prolonged delay of the judicial investigations with respect to complaints of torture".

In the following table the CPT has collected the cases that it has accessed of public employees that have appeared during 2007 in different Spanish courts. As we see the number of public employees that reach a judgement is very low in comparison to the complaints filed, as is the total number of public employers sentenced which is much less than those submitted to process. One must also note that the government grants "indulto" (pardon) to a significant amount of the few public employees that are finally sentenced.

Table 3. Processal situation of public employees reported in 2007

\begin{tabular}{|l|l|l|l|}
\hline & Denounced & Absolved & Condemned \\
\hline CN de Policía (National Body of Police) & 425 & 129 & 28 \\
\hline Guardia civil (Civil Guard) & 117 & 21 & 17 \\
\hline Policía Local (Local Police) & 369 & 90 & 49 \\
\hline Mossos d'Esquadra (Catalana Autonomous Police) & 133 & 14 & 8 \\
\hline Ertzaintza (Basque Autonomous Police) & 21 & 9 & 1 \\
\hline Policía Foral (Navarre Autonomous Police) & 20 & 8 & 0 \\
\hline Otras P. Autonómicas (Ahother Autonomous Police) & 1 & 0 & 0 \\
\hline Funcionarios Prisión (Prison Workers) & 140 & 24 & 0 \\
\hline Others & 20 & 5 & 2 \\
\hline TOTAL & 1246 & 300 & 105 \\
\hline
\end{tabular}

Source: CPT [31].

In this sense, there have been several sentences taken by the Constitutional Court and the Court of Human Rights in Strasbourg in recent years claiming that the Spanish authorities had not done enough research about various complaints of torture, noting errors in the system guarantees ${ }^{20}$.

An example of this lack of investigation made it to the Strasbourg Court of Human Rights. In the summer of 1992, around forty members of the Catalan independence movement were arrested during an antiterrorist operation headed by Baltasar Garzón, just before the Barcelona Olympic Games. Most of the detainees reported having been subjected to torture. The case was eventually taken to the Strasbourg Court of Human Rights, which published its verdict on the $2^{\text {nd }}$ of November 2004, concluding that it was impossible to determine whether torture had taken place, after such a long time, but there had certainly been a violation of Article 3, insofar as there had been no investigation of the complaints and the evidence that suggested torture might have indeed occurred ${ }^{21}$. Another similar process is Egunkaria case. In February 2003, due to the closure the Egunkaria newspaper and Martxelo

\footnotetext{
${ }^{20}$ See [38], pg. 9: In the recent years there has been several sentences: SSTC 52/2008, 14 April; 63/2008, 26 May; 69/2008, 23 June; 107/2008, 22 September; 123/2008, 20 October; 40/2010, 19 July and the pronouncement made by Court 1 on 18 October 2010 (RA 9398/2005). In this same respect, the SSTEDH of 2 November 2004, (Martínez Sala and others vs. Spain), and 28 September 2010, (San Argimiro Isasa vs. Spain) 3rd Section, R. no. 2507/07. Also there are SSTEDH of 8 March 2011 (Beristain Ukar vs Spain), SSTC 63/2010, 18 October.

21 See PIQUÉ [37].
} 
Otamendi director and other workers were arrested. After 5 days of incommunicado detention, they denounce torture. Similarly to the previous case, the Strasbourg court declares, in 15th of October 2012, that the Spanish State violated Article 3 of the European Convention on Human Rights by failing to investigate the allegations of torture enough.

Also, some torture condemned officials have been rewarded, as it happened in 2006 October with Manuel Allué -an Officials' Union leader rewarded by the FSP-UGT Union, "on recognition to his personal trajectory" (in an act where there were members of the Catalonian Government). Allué has been denounced several times by torture and ill treatment, and has been condemned once by "unnecessary rigor" against an imprisoned man.

\section{- The criminalisation of those who report these violent offences (individuals or collectives)}

Another element of this machinery of impunity is the criminalisation of defenders of human rights that work in the ambit of the struggle for the eradication of the torture in State. In this vein the CPT has referred in 2008 to a report to diverse international organizations titled Disqualification, obstruction and criminalisation of the activities of social organizations and professionals that report torture Spain and denounce these types of practices ${ }^{22}$. In the report 24 cases are highlighted, structured in four types of criminalisation: a) insults, threats and disqualifications; b) obstruction of activities (aggressions, not allowing access and economic penalties); c) penal or civil charges; and d) terrorism accusations.

It must be specially mentioned (based on the gravity of the case) the Summary 33/01 against Gestoras Pro Amnistía/Askatasuna, Basque anti-repressive organizations. In this trial 27 people were accused of "belonging to an armed band" because they were militants in those organizations, publicly and legally, supporting Basque prisoners. In the final sentence, made public on 2008 September 17 th, 21 people were condemned to 8 and 10 years of imprisonment. Other examples could be those of penal charges and denounces against individuals or associations for denouncing tortures. These denounces come out from the public prosecutor, the officials accused of torture or others. Some of the denounced Defenders are the Asociación Pro-Derechos Humanos de Andalucía (APDHA) from Huelva, Asociación de Seguimiento y Apoyo de Pres@s en Aragón (ASAPA) from Zaragoza, Asociación Contra la Tortura (ACT) from Madrid, Fran Buey (PreSOS) from Galiza, Aiert Larrarte (TAT) and Julen Larrinaga (Askatasuna) from Basque Country.

This report has been referred to Mrs. Hina Jilani, special representative of the General Secretary about the situation of the defenders of human Rights, that expressly requested from Spanish civil society information about the situation of the defenders of human rights and the measures taken at the National level for the implementation of the "Declaration about the Rights and responsibilities of individuals, groups, and institutions to promote and protect human rights and universally recognised fundamental freedoms"23. This criminalisation must be understood as an obstacle in the struggle against torture and the attempt to suppress the activity of people and collective defenders of human rights. The United Nations emphasizes "the valuable labour that carry out individuals, groups and institutions to contributing to the effective elimination of all violations of human rights and fundamental liberties of peoples and individuals" 24 and recognizes however that "given its participation in the struggle in favour of human rights, the defenders are often the first victims of violations of human rights perpetrated by public employees or private entities" 25 .

- Non-reparation (symbolic or material) of torture victims.

The Barcelona Recommendations [40] state: "persons who have suffered torture or ill treatment must receive an adequate solution and reparation, including recognition of the damage done, rehabilitation, compensation, satisfaction of needs arising from their personal situation and a guarantee of non-repetition". In the Spanish case, there is hardly ever any reparation for victims of

\footnotetext{
22 See CPT [39].

23 Resolution 53/144 approved 9th December 1998 by the General Assembly of the United Nations.

24 Extract of the Resolution 53/144.

25 Extract of the Report of the UN Secretary-General: A/55/292 of 11th August 2000.
} 
torture. Treatment of torture victims remains an outstanding issue for the judiciary in most European countries. It can be said that in the country that is the subject of this paper there are mechanisms to channel assistance for victims of various kinds of violence, but not for victims of violence exerted by government employees. It is therefore necessary to work on this issue.

\subsubsection{Torture and The Institution of Deprivation of Freedom}

Lastly, in prisons, detention centres of immigrants and minors and other centers of deprivation of freedom numerous episodes of torture and ill-treatment have been registered. Despite the opaqueness of the walls that separate prison and society, a constant drip exists of reports of infringements of the right to physical and psychological integrity of people that inhabit these spaces of imprisonment. The majority of reported cases, although with difficulty, are made through family and friends, lawyers and organizations in defence of human rights. The cases of ill-treatment and prison torture have two origins: those that are suffered everyday and those that are produced in exceptional circumstances.

In reference to the first origin, one should consider the degradation of the conditions of life of those people who inhabit prison and do not receive those rights that are inalienable to everyone like health, education, political participation or intimacy amongst others ${ }^{26}$ (Rivera [41]). This situation makes those people more vulnerable, given that it makes possible the appearance of situations of illtreatment (and sometimes torture); in some case by action (abuse by public employees), in others by omission (bad conditions of health, or hygiene and denial of intimacy...). To these bad conditions one can add the difficulty of establishing communication with the outside world, being the opaque spaces most inclined to abusive practices. The deprivation of freedom should not lead to the deprivation of any other right as is noted by the guaranteed regulations that should govern whatever state of law. In this vein we remember the words of the Italian Associazione Antigone [42], "The transparent prison that is obstinately pursued is probably unobtainable, but only a tension towards it, the illuminating appearance to a punishment merely the deprivation of personal freedom, undresses the extra legem accessories sentences that each detention carries with it, can constitute a barrier to the natural tendency of the prison to overcome its own limits, to sweep away the confessional justifications that each society finds in order for it".

Penitentiary overpopulation is an alarming issue, which affects every daily life aspect of imprisoned people: accommodation, hygiene, health, personal relations with other prisoners or officials, violence, etc. In fact, the Spanish State is the first among the Europa-15 in its imprisoned population figures. Spain has an index of 159,7 of prison population rate per 100,000 inhabitants, on 1 rt. September of 2008 and also in the same date it was an index of 141,9 prison density per 100 places. This invites us to think about the populist Legal reforms in a more punitive way27. Other worrying question is sick prisoners. On the Spaniard Legislation is established that seriously sick or terminal patients must be released ${ }^{28}$ but there are many cases of prisoners that are not released or they are liberated hours before dying. In fact, the Spanish Government has recognised 720 deaths in prison in the periode 2004-2007. We believe more credible the information of Catalonian Government Penitentiary Service that recognised 243 deaths for the same period ${ }^{29}$. If we considered that imprisoned people in Catalonia is a 13\% of the total Spaniard prisoners, we could suppose that death people within the Spaniard Penitentiary System is twice or three times the figure recognized by the Government ${ }^{30}$. Deaths in prison are the most serious of the many sanitary problems of the Spaniard prisons. Close to $12 \%$ of those deaths are suicides, which carries us to the mental health question. On this issue, the APDHA in a 2007 Report denounced that a 48\% of imprisoned people in the Andalucía

\footnotetext{
26 On the Health question, the main problem is that the Prison Sanitary System is not the same that for the rest of the Spaniard population, what put in question the general right to health of imprisoned population

27 See official figures from the Council of the Europe. Annual Penal Stadistics (March 2010).

28 Arts. 104.4 and 196 of the "Reglamento Penitenciario" (Prison Rules) and art. 92 of the Penal Code.

${ }^{29}$ See: www20.gencat.cat/docs/Justicia/Documents/ARXIUS/butlleti_serveis_penitenciaris_juliol2008.pdf

30 Centro de Documentación contra la Tortura (CDCT) esteems in 1900 the number of deaths under custody between years 2004 and 2007.
} 
prisons have mental diseases, and an $8 \%$ with serious mental diseases ${ }^{31}$.

In reference to the second origin of the torture in places of deprivation of freedom one should note that ill-treatment and torture are related to exceptionality that is produced in times of important conflict in prisons, such as riots and revolts. The majority of these conflicts entail reprisals and punishment; some legal, others alegal or illegal. Testimonies of prisoners relate terrifying episodes once "the calm has been established". Again, the lack of contact with the outside world facilitates these practices of revenge and their impunity (OSPDH [44]). In the 2004-2007 period CPT Reports compiled 354 tortures and ill-treatment denounces in prison, the majority of them came out from the "Primer Grado" (isolated regime). For example, in Quatre Camins Prison (Barcelona) after the 2004 April 30th revolt, there were systematic beatings against inmates, as the Catalonian Government recognised in 29 cases, though they had still not been judged being the officials on service. The case is in the Tribunal (CPT Report of 2004, 2005, 2006 and 2007). We can point out too the existence of torture denounces coming out from Minors centres. In 2004 and 2005 we published several denounces from Valle Tabarés Centre (Tenerife) about several irregularities, ill-treatments, sexual abuse (one minor was raped), and the death of a minor in strange circumstances. These situations finally ended in a Judicial Commission that found illegal punishment material as chain and iron fetters and shackles ${ }^{32}$.

\section{Citizenship and democratic culture: between structure and action}

Once the static and dynamic elements that affect the persistence of the use of torture in the Spanish State have been described, it is necessary by referring to the difficulties in the path of consolidating a civic and democratic culture in this country. When citizens do not demand strict adherence of rights and liberties, it is easy for cracks to appear in the rule of law. A liberal, guaranteeoriented system cannot arise from nothing, and 40 years of dictatorship did little to aid this. Thus, we are talking about symbolic elements, which nevertheless are very important, because they perpetuate a punitive populism that aids the existence and persistence of the use of torture. In this sense, an indicator may be the treatment that the media gives to cases of torture. Most media (including major ones, such as El País and El Mundo, or TVE) silence this fact or when this is not possible, they justify it based on information obtained from government sources or from the police. 33 .

Although this is true, paradoxically, in Spain there are important social networks and organizations that fight against torture. Perhaps the cruelty and extent of this scourge in the country has been an important factor for community development. In 2004 the CPT was created, a platform created by more than 40 organizations, associations, professional and academic struggling against torture and defending human rights. These organizations endorse the conclusions reached as the result of the debate of the Conference held in Barcelona on February $3^{\text {rd }}$ and 4th, 2006 and pledge to work for its full implementation as the highest expression of the eradication of torture in Spain [40]. The CPT works in coordination with Amnesty International (AI), Association for the Prevention of Torture (APT), or the World Organisation Against Torture (OMCT) and is a source of information and dialogue with international UN and Council of Europe agencies. It also fulfills a function of lobbying with state and national public institutions, as well as raising awareness of the citizens. In this sense we can say that the most successful scope of work has been in the international arena. International agencies and human rights associations have endorsed reports, diagnoses and recommendations from organizations of the CPT (see last paragraph of the first section of this article.) However, the impact on Spanish public

\footnotetext{
${ }^{31}$ About mental diseases and prison see APDHA [43].

32 About minors problematic see ASAPA [45].

33 It should be noted, by contrast, that alternative media (such as Gara or Diagonal) repeatedly echo complaints of torture, serving as the voices of social organizations. It is interesting the role played by the Catalan and Basque media (especially public broadcasting). In some specific cases highlighted by the existence of convincing evidence (the case of Unai Romano), the social relevance of the victims (managers of the newspaper Egunkaria) or widespread social rejection against some arrests (Catalan nationalists detained in 1992) they have made a thorough communication of the cases. About media and torture see Cabezas / Velilla [46].
} 
institutions (legislative amendments and / or development of public policies and programs) has been rather small. Despite the surplus of legitimacy and credibility from reports and recommendations of international organizations to the work of these social organizations, few things have moved in public institutions.

It would be necessary, for the magnitude of cases identified as well as through repeated criticism from international organizations and human rights associations, to proceed to the elaboration of a National Plan Against Torture. This should have the involvement of various ministries (interior, justice, health...) as well as institutions of different territorial levels (Euskadi and Catalonia have transferred most of the competencies of security matters, and in the case of the latest also the prison system). So far there have only been small actions in areas where there are significant territorial social work organizations: in Catalonia they have installed video surveillance cameras in some police stations, in Euskadi they have prepared the Ertzaina Protocol, which also contains video recordings and other partial measures. In any case, we can say that the performances are still very weak due in part to a costbenefit calculation. There is little social demand of the citizenry of such measures (and few electoral gains) and on the other hand they are uncomfortable for police organizations and unions and prison officials. These measures, therefore, are not carried out by a kind of carelessness of the authorities, if public opinion demanded it action could be developed to make public policies more profound and solid.

Now there is a second area of action, one that has to do with the exceptional, in which no action is entirely voluntary. The existence of torture is a fundamental element in the Spanish anti-terrorist struggle. Thus, it is useful to the state that this scourge exists. Although systematic criticism received from international agencies and human rights associations, it is very difficult for the State to renounce it (see for example the flat refusal every time an international body recommends abolishing the incommunicado detention). For the Spanish government this practice serves to generate and spread terror (all activists know that if they are detained under anti-terrorism legislation they have a good chance of being brutally tortured); accuse people without proof (it should be noted that preventive detention can last up to four years) or even in some cases to obtain information (although the latter would be probably the least important).

To begin to struggle in the cultural field in the short-term, it would require an intervention along three lines of action:

\section{- Acknowledgement by public authorities of the existence of torture.}

There has not been acknowledgement of the existence of torture and ill treatment by the authorities, which try to systematically hide this reality. The first step to face the problem is to recognize the fact that it exists and to make a commitment to confront it with concrete measures. Thus, the UN Special Rapporteur for the Question of Torture, Theo van Boven, in his report of 2004 said: "The highest authorities, in particular those responsible for national security and law enforcement, should officially and publicly reaffirm and declare that torture and cruel, inhuman or degrading treatment or punishment are prohibited under all circumstances and that information on and allegations of the practice of torture in all its forms will be promptly and thoroughly investigated."

\section{- Ensuring ever-increasing accountability of spaces of deprivation of freedom.}

This accountability is necessary in order to achieve a double aim: to guarantee the fundamental rights of people under arrest or in prison and to guarantee the right and the duty of a society to be informed of what happens inside these institutions. The first aim is evident: lack of communication with the outside is in itself a violation of the rights of detainees. The punitive power of the State deprives these persons of their freedom, but not of other rights, such as the right to communicate with relatives, friends, lawyers, doctors or whomever else they wish to communicate with. Furthermore, the opacity of the walls of detention and internment centres allows (and may even encourage) the existence of torture or ill treatment, as pointed out by international organisations and human rights groups.

The second aim may not be as evident, but is nevertheless equally important. In democratic countries, we accept the delegation of violence and punitive power in the State as a part of the rules of 
the game, but not at any price. Rather, this is done on the basis that all people, with no discrimination whatsoever, must have their dignity respected -wherefrom we establish substantial and procedural guarantees within the law. Having said this - if society delegates on to the State -, society has the right and the duty to be informed of what happens inside detention and internment centres.

- Creation of mechanisms that allow citizen control of what happens in these reclusion centres, changing the composition and functions of the Spanish national Mechanism for the Prevention of Torture .

In 2008, the UN Committee of Human Rights stated that "The member State must accelerate the process of adoption of a National Mechanism for the Prevention of Torture, in accordance with the Optional Protocol to the Convention against Torture and other Cruel, Inhuman or Degrading Treatment or Punishment, and taking the recommendations of the various international organisations and experts and the opinion of civil society and all the NGOs taking part in the struggle against torture into account". The current National Mechanism exists. The first report was published in 2010. Nevertheless its composition and functions do not satisfy the expectations of national and international social organizations. Major changes in composition and functions would be necessary to operate in order to transform this as a true citizen control mechanism.

\section{Conclusions: To a program of action for the eradication of torture and ill-treatment}

The eradication of torture and ill-treatment should be a priority action in the political program of every country in the world. The respect to the physical and psychological integrity of a people deprived of freedom has to be placed above other considerations. In this sense, numerous international treaties and State laws introduce the mandate of absolute prohibition of torture, as well as the demand to carry out public policies and legislative reforms in order to struggle against its perpetration. The double moral of our democracies, however on the one hand leads us to indignation reporting violations of human rights that are produced in far away contexts, and at the same time hides the crude reality that is being lived in the Spanish State in relation to this problem. As has already been noted, hundreds of cases of torture and ill-treatment are reported each year in the Spanish State.

We have affirmed the reiterated presence of numerous cases, the majority of which registered by NGOs and we have been investigating why there is a survival of this phenomena in a democratic State like Spain. We have highlighted two historical and political specifics that can help us to understand the current situation: the construction of a culture of emergency in order to confront the phenomena of armed violence, as well as the late democratic recuperation of the state at the end of the seventies. Understanding the context highlights the static and dynamic elements that intervene in the existence of this type of State violence, by means of tools that are offered by legal science, sociology of law and the analysis of public policy. These elements form the base to enable the development of objectives of action for the eradication of torture. One must take into consideration that this institutional violence responds to a multiplicity of factors and therefore political action should be orientated to various fields, all complementary.

Firstly to achieve the abolishment of certain elements in legislation, such as the concept of incommunicado detention, determined types of penitentiary isolation or "indulto" (pardon) for torturers.

A second field makes reference to the demands of public policies orientated towards the eradication of practices of torture and ill-treatment that is necessary to be developed by all levels of jurisdiction. These policies have to be developed with the objective to put an end to the illiberal practices that put in doubt guarantees and human rights that are produced in the framework of the three institutions of the penal system: the police apparatus, the courts and the institutions of the deprivation of freedom.

A third field is related to the diffusion of a political democratic culture in our society, an 
awareness in search of the demands with respect to guarantees and fundamental rights, or in other words, stop considering it "normal" that in a democratic state, torture is carried out.

\section{Acknowledgments}

A lot of the information and reflections collected in this article must be understood as the result of a collective work in the framework of the Coordinator for the Prevention of Torture. This article is dedicated to all those people and groups who work in favour of human rights. I would like to thank Carlos Hernandez for the report he wrote for the CPT before the UN Human Rights Committee evaluation, from which I have extracted several paragraphs; and Rachel Palmen and Ander Larunbe for her/his help with the English translation of this article. Para ti, Mikel.

\section{$\underline{\text { References }}$}

1. Coordinadora para la Prevención de la Tortura (CPT) (2011): Informe sobre la tortura en el Estado español en el año 2012, http://www.prevenciontortura.org/wp-content/uploads/2013/05/INFORME-CPT-2012-final.pdf

2. Ferrajoli, Luigi (2008): “La batalla contra la tortura: la batalla de la razón”, in OSPDH, Privación de libertad y derechos humanos. La tortura y otras formas de violencia institucional, Barcelona: Icaria, pp. 17-20.

3. Sottas, Eric (2008): “La tortura: relativismos político, cultural y económico. El choque de las convicciones”, in OSPDH, Privación de libertad y derechos humanos. La tortura y otras formas de violencia institucional, Barcelona, Icaria, pp. 1315.

4. Subirats, Joan/ Knoepfel, Peter/ Larrue, Corinne/ Varone, Frédéric (2008): Análisis y gestión de políticas públicas, Barcelona: Ariel.

5. Van Swaaningen, Réné (1999): "Reclaiming critical criminology: Social justice and the European tradition", Theoretical Criminology, 3(1), pp. 5-28.

6. Cid, José/ Larrauri, Elena (2001): “Criminología crítica”, Teorías criminológicas, Barcelona: Bosch.

7. Del Cura, Jorge (2006): “Derechos fundamentales y privación de libertad en el Estado español", Bergalli/Rivera, Torturas y abuso de poder, Barcelona: Anthropos, pp. 108-121.

8. Del Cura, Jorge (2008): "Panorámica de la tortura y de las muertes bajo custodia en el Estado español: las denuncias en el último quinquenio", in OSPDH, Privación de libertad y derechos humanos. La tortura y otras formas de violencia institucional, Barcelona: Icaria, pp. 207-238.

9. Website of Committee for the Prevention of Torture of Council of Europe http://www.cpt.coe.int/en/states/esp.htm

10. Arzuaga, Julen (2007): "Medidas de excepción: el caso vasco", Contrapoder, 10.

11. Arzuaga, Julen (2008): "La situación de las personas privadas de libertad en aplicación de la legislación antiterrorista", in OSPDH, Privación de libertad y derechos humanos. La tortura y otras formas de violencia institucional, Barcelona: Icaria, pp. 335-372.

12. Guittet, Emmanuel-Pierre (2006): La genèse de la cooperation antiterroriste en Europe et l'implication de l'Espagne dans la (re)definition de l'identité européene. De la raisos d'Etat à la raison de la gouvernnementalité européene?, $\mathrm{PhD}$ disertation, Université de Nanterre.

13. López-Garrido, Diego (1987): Terrorismo, Política y Derecho. La legislación antiterrorista en España, Reino Unido, República Federal de Alemania, Italia y Francia, Madrid: Alianza.

14. Baratta, Alessandro/ Silbernagl, Michael (1983): "La legislazione dell'emergenza e la cultura giuridica garantista nel processo penale”, Dei delitti e delle pene, 3, pp. 543-580.

15. Bergalli, Roberto (1988): “Introducción”, in Serrano, José Ramón, Emergencia y crisis del Estado social. Análisis de la excepcionalidad penal y motivos de su perpetuación, Barcelona: PPU, pp. 1-16.

16. Ferrajoli, Luigi (2004): Diritto e ragione. Teoria del garantismo penale, Bari: Laterza (1989).

17. Ubasart, Gemma (2008): Conflicte i Estat: La construcció de la cultura de l'emergència a Europa. Una aproximació al comprativa al cas italià i espanyol, $\mathrm{PhD}$ disertation, Universitat Autònoma de Barcelona.

18. Bruni, Luigi (1987): ETA. Historia de la lucha armada, Tafalla: Txalaparta.

19. Casanova, Iker (2008): ETA 1958-2008. Medio siglo de historia, Tafalla: Txalaparta. 
20.

Ibarra, Pedro (1989): La evolución estratégica de ETA, Donosti: Kriselu.

21. Crenshaw, Martha (1972): “The Concept of Revolutionary Terrorism”, The Journal of Conflict Resolution, 16(3), pp. 383-396.

22. Ruggiero, Vincenzo (2006): La violenza politica, Bari: Editori Laterza

23. Bigo, Didier/ Bonelli, Laurent/ Guittet, Emmamuel-Pierre/ Olsson, Christian/ Tsoukala, Anastassia (2006): Illiberal practices of liberal regimes: the (in)security games (2006), París: Centre d'Études sur les Conflits/L'Harmatan.

24. Rivera, Iñaki (2004): "State form, labour market and penal system. The new punitive rationality in context", Punishment and Society, Vol. 7(2), pp. 167-182.

25. Jaime-Jiménez, Óscar (1996): “Orden público y cambio político en España”, Revista Internacional de Sociología, 16, pp. 143-167.

26. Bergalli, Roberto (2003) (coord.): Sistema penal y problemas sociales, València: Tirant lo Blanch.

27. Orbegozo, Izaskun / Perez, Ana Isabel / Pego, Laura, (2009): La suspensión individual de derechos en supuestos de terrorismo: especial consideración de la detención incomunicada, Vitoria-Gasteiz: Ed. Ararteko, Colección de Derechos Humanos "Juan San Martín".

28. Dirección de Derechos Humanos del Gobierno Vasco (2009): Documentación de la tortura en detenidos incomunicados en el País Vasco desde el 2000 al 2008: abordaje científico., http://www2.ohchr.org/english/bodies/cat/docs/ngos/AEDIDH2_Spain43.doc

29. De la Cuesta, José Luís / Muñagorri, Ignacio (Dir.) (2009): Aplicación de la Normativa Antiterrorista, San Sebastián: Instituto Vasco de Criminología, http://www.ivac.ehu.es/p278content/es/contenidos/informacion/ivckei libro online/es libro/normativa.html

30. Cabrera, Pedro José/ Rios, Julian Carlos (2002): Mirando el abismo: El régimen cerrado, Madrid: Universidad Pontificia Comillas.

31. Coordinadora para la Prevención de la Tortura (CPT) (2008): Informe sobre la tortura en el Estado español en el año 2007, http://www.prevenciontortura.org/Informe2007/INFORME CPT 2007.pdf

32. Fernàndez, David (2007): Cròniques del 6 i altres retalls de la claveguera policial, Barcelona: Virus.

33. Fernàndez, David/ Ubasart, Gemma (2008): "La situación de las personas detenidas por protestas u otras manifestaciones de disidencia política", in OSPDH, Privación de libertad y derechos humanos. La tortura y otras formas de violencia institucional, Barcelona: Icaria, pp. 373-383.

34. Della Porta, Donatella (1995): Social Movements, Political Violence and the State. A comparative Analysis of Italy and Germany, New York: Cambridge University Press.

35. Della Porta, Donatella/ Reiter, Herbert (2003): Polizia e protesta. L'ordine pubblico dalla Liberazione ai "no global", Bologna: Il Mulino.

36. Amnistía Internacional (2007): Sal en la herida. La impunidad efectiva de agentes de policía en casos de tortura y otros malos tratos, www.es.amnesty.org/uploads/tx useraitypdb/Sal en la herida.pdf

37. Piqué, Ramon (2006): "El tribunal de Estrasburgo y la garantía de los derechos humanos en personas privadas de libertad. El caso de los independentistas catalanes detenidos durante la operación Garzón", in Bergalli/ Rivera, Torturas y abuso de poder, Barcelona: Anthropos, pp. 122-132.

38. Ararteko, Defensor del Pueblo del País Vasco (2008): Estudio sobre el sistema de garantias en el ámbito de de la detención incomunicada y propuestas de mejora, http://www.ararteko.net/RecursosWeb/DOCUMENTOS/1/5_2093_3.pdf

39. Coordinadora para la Prevención de la Tortura (CPT) (2008): Descualificación, obstrucción y criminalización de actividades de organizaciones sociales y profesionales que denuncian tortura en el Estado español (actualización febrero 2009), Madrid: CPT.

40. Coordinadora Catalana per a la Prevenció de la Tortura/ Organització Mundial Contra la Tortura (CPT/OMCT) (2007): Violacions de Drets Humans a l'Estat Espanyol, Barcelona: CPT/OMCT.

41. Rivera, Iñaki (2006): La cuestión carcelaria. Historia, epistemología, derecho y política, Buenos Aires: Editores del Puerto.

42. Associazione Antigone (2000): Il carcere transparente. Primo raporto nazionale sulle condizione di detenzione, Roma: Castelvechi.

43. APDHA (2007): Enfermos mentales en las prisiones ordinarias: un fracaso de la sociedad del bienestar, www.apdha.org/media/saludmental07.pdf

44. Observatori del Sistema Penal i els Drets Humans (OSPDH) (2004): L'empresonament a Catalunya, Barcelona: Edicions de 1984 
46.

Cabezas, Sílvia/Velilla, Javier (2008): "El discurso mediático en el tratamiento de la tortura en el Estado español”, in OSPDH, Privación de libertad y drerchos humanos: la tortura y otras formas de violencia institucional en el Estado español, Barcelona: Icaria.

\section{Annex. Recommendations of international organizations}

Committee Against Torture of the United Nations (2002), Conclusions and recommendations of the Committee against Torture: Spain, $\underline{\text { CAT } / C / C R / 29 / 3 . ~}$

Committee Against Torture of the United Nations (2011), Conclusions and recommendations of the Committee against Torture:

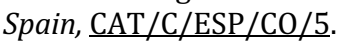

Committee for the Prevention of Torture of Council of Europe (2003) Report to the Spanish Government on the Visit to Spain Carried Out by the European Committee for the Prevention of Torture and Inhuman or Degrading Treatment or Punishment (CPT) from 22 to 26 July 2001, CPT/Inf(2003)22.

Committee for the Prevention of Torture of Council of Europe (2013) Report to the Spanish Government on the Visit to Spain Carried Out by the European Committee for the Prevention of Torture and Inhuman or Degrading Treatment or Punishment (CPT) from 31 May to 16 June 2011, CPT/Inf(2003)22.

Comission of Human Rights of the United Nations (2004), Report of Special Rapporteur for the Question of Torture, Theo van Boven, Visit to Spain, E/CN.4/2004/56/Add.2.

Commissioner for Human Rights of Council of Europe (2005), Report by Alvaro Gil-Robles, Commisioner for Human Rights, on this visit to Spain, 10-19 Marh 2005, Com.H.(2005)8.

Human Rights Committee of United Nations (2008), Examen des rapports présentes par les états parties conformément á l'article 40 du Pacte. Observations finales du Comité des droits de l'homme: Espagne, 94 period of sessions, 13-31 0ctober 2008, CCPR/C/ESP/CO/5/.

Human Rights Council of the United Nations (2008), Report of the Special Rapporteur on the promotion and protection of human rights and fundamental freedoms while countering terrorism, Martin Scheinin - Mission to Spain, A/HRC/10/3/Add.2 